\title{
共同体からの疎外意識が主観的幸福感に及ぼす 影響に関する研究
}

\author{
北川 夏樹 1 - 鈴木 春菜 $2 \cdot$ 羽鳥 剛史 3 ・藤井 聡 4 \\ 1学生会員 京都大学大学院 工学研究科（† 615-8540 京都市西京区京都大学桂4） \\ E-mail: kitagawa@trans.kuciv.kyoto-u.ac.jp \\ 2正会員 山口大学大学院助教 理工学研究科（三755-8611 山口県宇部市常盤台2-16-1） \\ E-mail: suzuki-h@yamaguchi-u.ac.jp \\ 3 正会員 東京工業大学大学院助教 理工学研究科（广152-8552 目黒区大岡山2-12-1） \\ E-mail: hatori@plan.cv.titech.ac.jp \\ 4正会員 京都大学大学院教授 工学研究科（干615-8540 京都市西京区京都大学桂4） \\ E-mail: fujii@trans.kuciv.kyoto-u.ac.jp
}

\begin{abstract}
本研究では，「家族」，「学校や会社等の組織」，「地域」，「国家」という4つの共同体を取り上げ て，これらの共同体からの疎外意識が主観的幸福感に及ぼす影響について実証的に検討することを目的と した。この目的の下，主観的幸福感を構成する「感情的幸福感」と「認知的幸福感」に関する既存尺度と ヘーゲルの理論を基に作成した「人間疎外尺度」を用いて，両者の関連を検討した，その結果，共同体に 対する疎外意識と主観的幸福感との間に負の関連性が示され，共同体からの疎外意識を感じている人ほど， その幸福感が低い傾向にある可能性を示唆する結果が得られた．特に，「家族」と「国家」に対する疎外 意識は, 感情的幸福感と認知的幸福感の双方に対して直接的な負の影響を及ぼし得る可能性が示唆された.
\end{abstract}

Key Words : subjective well-being, alienation scale, belongingness, Hegel's "The Phenomenology of Spirit"

\section{1. はじめに}

\section{（1）主観的幸福感と共同体意識}

土木事業は人々の生活に多大な影響を及ぼす。国土・ 地域計画においては，国民や地域住民の幸せな生き方や 暮らしを見据えながら，その実現に向けて土木事業を適 切に行うことが求められる.

それでは，人々が幸せな生活を営むための条件とはど のようなものであろうか.この問題に関して，これまで 心理学の分野を中心に「主観的幸福感 (Subjective WellBeing）」に関する研究が進められてきた.ここで, 「主観的幸福感」とは一般に「自分の生活の総体的な質 について，それが自分の要望や期待とどの程度合致して いるかに関わる主観的評価」と定義される1),2). これま で主観的幸福感の規定要因として, 健康, 収入, 婚姻, 教育, 職業, 宗教, 年齢, 性別等, 様々な要因が検討さ れてきた3),4)、その中でも，家族や組織等の共同体に対 する帰属 (belongingness) は人間の根源的な欲求である
と見なされており，共同体への帰属意識が主観的幸福感 を高める主要な要因の一つであると考えられている5),6 すなおち，人々はその本質において，安定的で親密な人 間関係に身を置くことを求めており，それ故，そうした 人間関係の形成やそこでの帰属意識の醸成が，人々にお いて満足感や喜びをもたらし，幸福感の増進を促すもの と考えられる. その一方で, 人間関係の喪失や帰属意識 の希薄化は，人々において不安や苦悩をもたらし，幸福 感を低下させるものと考えられる.

こうした共同体への帰属意識と人間の幸福感との関連 については，古くは共同体からの疎外の問題を論じたへ 一ゲルの思想にまで遡ることが出来る. すなわち，ヘー ゲルはその著書『精神現象学』7〕おいて, 近代化の進 展に伴い，人々が共同体的束縛から解放され，本来一体 であるべき共同体から疎外されていく過程を批判的に論 じたのである.ここで，ヘーゲルの論ずる「疎外」とは 人間精神がその本質を亦失した状態を指しているが， へ 一ゲルによれば，そうした「精神の本質」とはそれが共 
同体と一体的であるところにあると捉えられている。す なわち，「絶対の精神的存在たる共同体が，同時に現実 の意識として存在し，自分のすがたを対象化するに至っ たとき，それこそが精神なのである(ヘーゲル，1807； 長谷川訳 1998，p.297)」と論じられているように，へー ゲルは人間の精神を本質的に共同体的なものであると捉 えている.このヘーゲルの論考に拠れば，共同体から疎 外されている個人は，本来的な精神の状態にあるとは言 い難い.ここで当然ではあるが，非本来的な状態と本来 的な状態とでは後者の状態にある人々の方がより「幸 福」であると感ずる傾向が高いと考えるなら，共同体か ら疎外されている個人が，少なくとも共同体に帰属して いる個人に比べて，幸福を感じているとは考え難いとい うこととなろう。

実際に既往研究において，以上の議論と整合的に，家 族，学校や職場，地域コミュニティ等，様々な共同体を 対象として，そこで親密な人間関係を形成しているか㧵 かが，その人の幸福感と強く関連していることを示唆す る結果が得られている. まず，婚姻は幸福感に最も強く 影響する要因の一つであるとの知見が得られており，家 族内の親密な関係やその関係に対する満足感が人々の幸 福感を高めるものと考えられている3), 。. また，学校や 職場において友人や同僚と共に時間を過ごすこと自体が, 人々の幸福感の増進に寄与すると考えられている ${ }^{8), 99}$.

一方，そうした交友関係から排除されることが不安感や 孤独感と強い関連を持つことが指摘されている10),11).さ らに，居住地域に対する愛着や地域コミュニティへの帰 属意識が地域住民の幸福感の醸成を促すことが示されて (る ${ }^{12), 13)}$.

\section{(2) 本研究の目的}

この様に, 既往研究において, 家族, 学校や職場, 地 域社会を対象として，これら共同体における人間関係や 共同体への帰属意識が主観的幸福感に影響する可能性が 示唆されている. それ故，冒頭で述べた様に土木事業が 人々の幸福な生活の実現に資するべきものである以上， そうした土木事業の計画立案にあたっては，各種の共同 体を適切に維持・形成することが重要な配慮事項である と考えられる.ただし，従来の研究より，家族や組織等 の共同体への帰属意識と主観的幸福感とが互いに関連し ている可能性が示されているものの, それぞれの関連の 深さは共同体ごとに異なる可能性が考えられる.しかし， これまでの研究では，それぞれの共同体に対する帰属意 識と幸福感との関連を個別に検討するに留まっており， 筆者らの知る限り，こうした関連の相違については十分 に検討されていないのが実情である，また，各種の共同 体に対する帰属意識が全体として人々の幸福感にどの程 度寄与しているかについても，実証的に明らかにされて
いないものと考えられる，以上に述べた様な各共同体意 識が幸福感に及ぼす効果の相違やその全体的な寄与を明 らかにすることは，現実の政策立案を進める上での基礎 的知見になり得るものと期待される.

さらに，これまでの研究においては，国家に対する共 同体意識であるナショナリズムについては取り上げられ ておらず，ナショナリズムと幸福感との関連については 実証的に検討されていない.ただし，「国」土の形成は，

「国」民のナショナリズムの涵養に少なからず影響を及 ぼし得るものであり，それ故，上述の検討事項に加えて， ナショナリズムの増進が人々の幸福感と関連しているか どうかを明らかにすることは，国土・地域政策を検討す る上で示唆するところが少なくないものと思われる.

以上の問題意識の下，本研究では，「家族」，「職 場・学校等の組織」,「地域」,「国家」という4つの 共同体を取り上げ，これらの共同体からの「疎外意識」， あるいは逆に言うなら「共同体意識」が主観的幸福感に 及ぼす影響について実証的かつ探索的に検討することを 目的とした. 本研究では，この目的の下，既往研究にお いて提案されている「主観的幸福感尺度」とヘーゲル 『精神現象学』を基に作成された「人間疎外尺度」を用 いて，両者の関連性について検討することとした。

\section{2. 調査}

\section{(1) 調査概要}

2009 年 11 月〜 12 月に京都大学の学生 160 名を対象に 紙面によるアンケート調査を実施した（男性 140 名，女 性 20 名, 平均年齢 23.15 歳, 年齢標準偏差 1.26 歳). 質 問項目は，大きく分けて「主観的幸福感(感情的幸福感， 認知的幸福感)」及び「共同体からの疎外意識」の 2 つ から成る.

\section{（2）主観的幸福感の測定尺度}

主観的幸福感は，日々の生活経験における肯定的な 感情と否定的な感情，及び，人生・生活全体への認知的 な満足感の三つの要素により構成されるものと考えられ ている ${ }^{14), 15)}$. ここで, 肯定的な感情と否定的な感情は併 せて「感情的幸福感（Affective SWB, AWB）」と呼称さ れ，人生や生活全体に関わる認知的な満足感は「認知的 幸福感 (Cognitive SWB, CWB)」と呼称されている. 本 調査では，それぞれの幸福感について，以下の方法に従 い質問項目を設けた.

\section{a) 感情的幸福感}

「感情的幸福感」の程度を量るため, Västfjäll \& Gärling (2007)を参考にして，感情の「水準(valence)」と「活性度 (activation)」に関する質問項目を設定した ${ }^{16)}$.まず，感情 の「水準(valence)」については，「うれしい一悲しい」， 
「幸せな一不幸な」，「快い一不快な」という各形容詞 のペアに対して，4 段階の感情水準を設定し（例えば,

「うれしい一悲しい」の場合，「とてもうれしい気持 ち」，「少しうれしい気持ち」，「少し悲しい気持ち」， 「とても悲しい気持ち」），それぞれの水準について 日々の暮らしの中でそうした感情を抱く頻度を「とても 頻繁に感じた」から「全く感じなかった」までの 5 件法 で尋ねた。一方，感情の「活性度(activation)」について は，「積極的な一消極的な」，「活発な一退屈な」，

「ハッキリした感じ一ねむたい感じ」という各形容詞の ペアに対して，「水準」を量る場合と同様に，4段階の 感情活性度を設定し（例えば，「積極的な一消極的な」 の場合，「とても積極的な気持ち」，「少し積極的な気 持ち」，「少し消極的な気持ち」，「とても消極的な気 持ち」），それぞれの活性度について日々の暮らしの中 でそうした感情を抱く頻度を「とても頻繁に感じた」か ら「全く感じなかった」までの5件法で尋ねた。

上記の各形容詞対について，以下の例に示すように， 感情の「水準」及び「活性度」の指標值を求めた。

例）「うれしい一悲しい」の場合

$3 \times$ (「とてもうれしい気持ち」を感じた頻度 $)$

$+1 \times($ 少しうれしい気持ち」を感じた頻度 $)$

$+(-1) \times($ 少し悲しい気持ち」を感じた頻度)

$+(-3) \times$ (「とても悲しい気持ち」を感じた頻度 $)$

上記の算定式より求めた感情の「水準」と「活性度」に 関する指標の加算平均加「感情的幸福感」の尺度を構 成した. この「感情的幸福感」尺度の信頼性係数は $\alpha=$ 0.87 であった。

\section{b) 認知的幸福感}

「認知的幸福感」の程度を量るための尺度として，

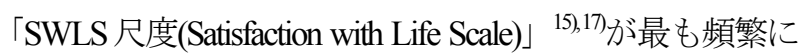
用いられており，本研究でもこの尺度を用いることとし た.「自分の暮らし」に対する評価に関する質問項目と して，「ほとんどの面で，“自分の暮らし”は理想に近 い」，「“自分の暮らし”は，とてもすばらしい状態 だ」，「私は“自分の暮らし”に満足している」，「私 は今まで，“自分の暮らし”のために必要とされる重要 な事柄を成し遂げてきた」，「私は，今の“自分の暮ら し”の全てを組み替えることができるとしても，ほとん ど何も変えないだろう」という5つの項目を設けた，そ して，各項目について「良く当てはまる」から「全く当 てはまらない」までの 7 件法で尋ねた。 なお，上記の SWLS 尺度項目の文言については大石(2009) ${ }^{18)}$ を参考にし て和訳した。

以上の 5 つ項目に対する回答值の加算平均から「認 知的幸福感」の尺度を構成した。「認知的幸福感」尺度 の信頼性係数は $\alpha=0.85$ であった.

\section{（3）共同体からの疎外意識の測定尺度}

「家族」「組織（学校，会社等）」「地域」「国家」 の 4つの共同体からの疎外意識の程度を量るための質問 項目として, 先行研究19),20)で提案された「人間疎外」尺 度を用いることとした。この尺度は，ヘーゲルの『精神 現象学』を基に作成されたものであり，4 つの共同体の それぞれについて，「一心同体感」「共同体全体の非認 知」「共同体への親近意識」「自己断念」「共同体への 奉仕」という5つの項目から構成される. ここで，「一 心同体感」は共同体と一心同体と感ずる程度を，「共同 体全体の非認知」は共同体が一人一人の人間関係の集合 に過ぎないと思う程度を，「共同体への親近意識」は共 同体を身近なものとして自然に感じる程度を，「自己断 念」は共同体のために自らを馴染ませるのは当然と考え る程度を，「共同体への奉仕」は共同体の利益のために 自己の利益を犠牲にする程度を表している．これらの項 目の内，「共同体全体の非認知」のみ，共同体加らの疎 外意識が高い状態を表しており，それ以外は踈外意識の 低い状態を表している.

各項目について，「共同体への奉仕」を除いて，「と てもそう感じる」から「全くそう感じない」の7件法で 回答を要請した。「共同体への奉仕」については，「自 分自身」（を優先する）から「家族全体（地域全体，組 織全体, 国家全体）」（を優先する）の7件法で回答を 要請した.

「家族」「組織」「地域」「国家」のそれぞれの共同 体について，5つの質問項目の加算平均から「人間疎 外」の程度を量る尺度を構成した。ただし，「家族」と 「組織」については，信頼性分析の結果，一部他の尺度 項目との相関が低い項目が見られたため, そうした項目 を除外することとした．各尺度の構成項目及びその信頼 性係数を表-1 に示す.

\section{3. 結果}

\section{（1） 疎外意識と主観的幸福感との相関分析}

まず，各共同体からの疎外意識と感情的幸福感及び認 知的幸福感との間で相関分析を行った。 その結果を表-2 に示す.この表に示すように，感情的幸福感については 全ての疎外意識との間に有意な負の相関が確認された. その相関の強さは，家族に対する疎外意識との相関が最 も強く $(r=-0.26, p<0.01)$, 次いで国家に対する疎外意 識との相関が強い $(r=-0.19, p<0.05)$ という結果となっ た. 次に, 認知的幸福感については, 地域に対する疎外 意識を除く，3つの共同体に対する疎外意識との間に有 意な負の相関が確認された，相関の強さは，家族に対す る疎外意識との相関が最も強 $<(r=-0.23, p<0.01)$, 次 いで組織に対する疎外意識との相関が強い（ $r=-0.22, p$ 


\section{表-1 人間疎外尺度の質問項目}

「人間疎外(家族)」信頼性係数 $(\alpha)=0.61$

·自分と自分の家族とは一心同体だという感じがする. (一心同体感)*

家族とは, 家族の中の一人一人の人間関係の集合にしかすぎないと思う。

(共同体全体の非認知)

・結婚した人はその新しい家族に自らをなじませるのが当たり前だと思う

(自己断念)*

•もしも自分一人の利益と家族全体の利益が対立したら, どちらを優先しますか. (共同体への奉仕) *

「人間疎外(地域)」信頼性係数 $(\alpha)=0.70$

·自分と自分の住んでいる地域とは一心同体だという感じがする. (一心同体感)*

·地域社会とは, 地域の中の一人一人の人間関係の集合にしかすぎないと思う. (共同体全体の非認知)

・自分は自分の住んでいる地域というものをとても身近なものとして自然に感じる. (共同体への親近意識) *

・自分が住んでいる地域に自らをなじませるのは当たり前だと思う

(自己断念) *

•もしも自分一人の利益と地域全体の利益が対立したら，どちらを優先しますか (共同体への奉仕)*

「間疎外(組織)」信頼性係数 $(\alpha)=0.60$

·自分と自分の属する組織(企業·学校等)とは一心同体だという感じがする (一心同体感)*

·企業や学校等の組織とは, 組織の中の一人一人の人間関係の集合にしか すぎないと思う. (共同体全体の非認知)

・自分は自分の所属する組織(企業·学校等)というものをとても身近なものとして 自然に感じる. (共同体への奉仕)*

「人間疎外(国家」信頼性係数 $(\alpha)=0.67$

・自分と国家は一心同体だという感じがする. (一心同体感)*

·国家とは, 国家の中の一人一人の人間関係の集合にしかすぎないと思う (共同体全体の非認知)

·自分は国家というものをとても身近なものとして自然に感じる.*

(共同体への親近意識) *

・自分が住んでいる国家のあり方に自らをなじませるのは当たり前だと思う. (自己断念)*

ももしも自分一人の利益と国家全体の利益が対立したら, どちらを優先しますか (共同体への奉仕)*

表-2 相関分析結果

\begin{tabular}{ccc}
\hline & \multicolumn{2}{c}{ 主観的幸福感 } \\
\hline & 感情的幸福感 & 認知的幸福感 \\
\hline 人間疎外 (家族) & $-0.259^{* * * *}$ & $-0.228^{* * * *}$ \\
人間疎外 (組織) & $-0.152^{*}$ & $-0.215^{* * *}$ \\
人間疎外 (地域) & $-0.133^{*}$ & -0.08 \\
人間疎外 (国家) & $-0.190^{* *}$ & $-0.148^{*}$ \\
\hline
\end{tabular}

$* * * p<0.01 * * p<0.05 * p<0.10$ (表中の数字は相関関数)

<0.01）という結果となった。認知的幸福感と地域に対 する疎外意識との間には有意な相関は認められなかった.

\section{（2）疎外意識と主観的幸福感との重回帰分析}

次に，各共同体からの疎外意識と主観的幸福感との直 接的な関連性を検討するため，主観的幸福感を構成する 感情的幸福感と認知的幸福感の 2 項目を従属変数に，4 つの共同体に対する疎外意識を説明変数とした重回帰分

析を行った. その結果を，感情的幸福感について表-3

に，認知的幸福感について表-4 に示す．表-3，表-4には， 説明変数間の重共線性を確認することを目的として，各 変数の VIF(Variance Inflation Factor)指標を記載している

この表に示すように，全ての説明変数について，その VIF 值が 2 以下であったことから，本調査データにおい て重共線性の影響は低いものと判断し，四つの人間疎外
表-3 感情的幸福感を従属変数とした重回帰分析結果 徉属変数: 感情的幸福感 $(n=160)$

\begin{tabular}{|c|c|c|c|c|c|}
\hline & B & $\beta$ & $\mathrm{t}$ & $\mathrm{p}$ & VIF \\
\hline (定数) & 8.354 & & 4.667 & 0.000 & \\
\hline 人間疎外(家族) & -1.045 & -0.246 & $* *-2.943$ & 0.004 & 1.198 \\
\hline 人間疎外(組織) & -0.232 & -0.057 & -0.678 & 0.499 & 1.212 \\
\hline 人間疎外(地域) & 0.306 & 0.078 & 0.785 & 0.433 & 1.704 \\
\hline 人間疎外(国家) & -0.768 & -0.192 & $* *-2.069$ & 0.040 & 1.473 \\
\hline $\mathrm{R}$ & & & 0.314 & & \\
\hline $\mathrm{R}^{2} 2$ & & & 0.099 & & \\
\hline
\end{tabular}

(B:非標準化係数, $\beta$ :標準化係数, $\mathrm{t}: \mathrm{t}$ 值, $\mathrm{p}$ :有意確率)

*** $p<0.01 * * p<0.05 * p<0.10$

表-4 認知的幸福感を従属变数とした重回帰分析結果 徉属変数: 認知的幸福感 $(n=160)$

\begin{tabular}{|c|c|c|c|c|c|c|}
\hline & B & $\beta$ & & $\mathrm{t}$ & $\mathrm{p}$ & VIF \\
\hline (定数) & 27.026 & & & 10.143 & 0.000 & \\
\hline 人間疎外(家族) & -1.313 & -0.207 & $* *$ & -2.476 & 0.014 & 1.198 \\
\hline 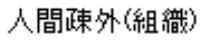 & -0.982 & -0.161 & $*$ & -1.919 & 0.057 & 1.212 \\
\hline 人間疎外(地域) & 0.814 & 0.139 & & 1.398 & 0.164 & 1.702 \\
\hline 人間疎外(国家) & -0.968 & -0.163 & $*$ & -1.754 & 0.081 & 1.471 \\
\hline $\mathrm{R}$ & \multicolumn{6}{|c|}{0.304} \\
\hline $\mathrm{R}^{2}$ & \multicolumn{6}{|c|}{0.092} \\
\hline
\end{tabular}

(B:非標準化係数, $\beta$ :標準化係数, $\mathrm{t}: \mathrm{t}$ 值, $\mathrm{p}$ :有意確率 $)$

$* * * p<0.01 * * p<0.05 * p<0.10$

尺度を独立した説明変数として扱うこととした。

まず，感情的幸福感については，表-3に示すように， 家族からの疎外意識と国家からの疎外意識がともに有意 な負の影響を有している傾向が認められた，一方，認知 的幸福感については，表-4 に示すように，家族からの 疎外意識と国家からの疎外意識に加えて，組織からの疎 外意識も有意に負の影響を有するという傾向が認められ た. 地域からの疎外意識については，感情的幸福感と認 知的幸福感ともに有意な影響は確認されなかった．2つ の回帰モデルの決定係数 $R^{2}$ についは，いずれも 0.1 程 度となった。

\section{4. 考察}

\section{(1) 結果のまとめ}

本研究では，「家族」，「組織」，「地域」，「国 家」の各共同体に着目し，それぞれの共同体に対する疎 外意識と主観的幸福感との関連について実証的かつ探索 的に検証することとした．検証するにあたり，ヘーゲル の理論を基に作成した「人間踈外尺度」と，主観的幸福 感を構成する「感情的幸福感」と「認知的幸福感」に関 する既存の尺度を用いた。

まず，相関分析の結果，感情的幸福感については全て の疎外意識と負の相関が認められ，認知的幸福感につい ては地域に対する疎外意識を除く $3 つ の$ 疎外意識と負の 
相関が認められた．また，重回帰分析の結果より，家族 と国家に対寸る疎外意識は，感情的幸福感と認知的幸福 感の双方に対して直接的な負の影響を持つという可能性 が示されたそそして，組織に対する疎外意識については, 認知的幸福感に対して直接的な負の影響を持つという可 能性が示された，なお，主観的幸福感は感情的幸福感と 認知的幸福感の双方から構成されることを踏まえれば, 組織に対する疎外意識がその一方の幸福感の尺度と有意 な関連性を持つとの結果は，それが主観的幸福感と一定 程度の関連を持ち得ることを示唆しているものと考えら れる.

従って，以上の結果は，少なくとも家族，組織，国家 については，これらの共同体に対する疎外意識が主観的 幸福感と負の関連を持つことを示唆しており，既往研究 で示されてきた，共同体への帰属意識が強い人々は主観 的に幸福であると感ずる傾向が強くなるという知見を改 めて支持するものであると解釈できる.

なお, 本研究の結果は, 大学生を対象とした限られた 調査データに基づいており, 分析結果の解釈にあたって は，その点に留意することが必要である．ただし，本調 查データにおいても, 既往研究と整合的な知見が得られ ているという以上の結果は, 本研究の分析結果に一定の 妥当性があることを示唆するものと考えられる. 無論, 後述するように，本研究の知見をより厳密に確認するた めには，今後，一般の地域住民を対象としたより広範な サンプルを用いた検討が必要であることは言うまでもな い.

\section{（2）共同体からの疎外意識が主観的幸福感に及ぼす影 響}

この様に本研究より，共同体からの疎外意識が主観的 幸福感に負の影響を及ぼす可能性が示された．このこと は，家族や国家，あるいは学校や会社等の組織から疎外 されている人ほど，そうでない人に比べて，日常生活に おいて「快い」といった肯定的な感情を抱く傾向が低く それとともに自分の生活に満足していない傾向にあるこ とを意味している. なお，重回帰モデルの説明力につい ては, いずれの分析においても決定係数 0.1 程度であっ た. 既往研究 ${ }^{21)}$ より, 主観的幸福感の分散の半分程度が 個人特性で説明できることが指摘されているが，本研究 の結果はその内のおおよそ 5 分の 1 程度が，4つの共同 体からの疎外意識（或いは共同体意識）の高低によって 説明できる可能性を示唆している.

特に, 4 つの共同体の内，家族に対寸る疎外意識につ いては，相関分析と重回帰分析の双方において，主観的 幸福感と最も強い負の関連を持つことが示された。この 結果は，婚姻の有無や家族関係の親密さが，主観的幸福 感に影響する主要因であるとした既往研究3) の 8)の結果と
整合的であると言える.

ただし，従来の研究では，国家に対する共同体意識に ついては検討されておらず，その主観的幸福感との関連 については明らかではなかった，そうした中，本研究で は，両者の関連を検討したところ，国家に対する疎外意 識が主観的幸福感と負の関連を持つという結果が得られ た.この結果は, 国家に対するナショナリズムが人々の 幸福感の醸成に寄与する可能性を示唆するものと言える. その一方で，本調査デー夕においては，地域に対する 疎外意識は，感情的幸福感との相関を除いて，主観的幸 福感と有意な関連性が認められなかった。こうした結果 が得られた理由については, 様々な原因が考えられると ころではあるが，その一つの可能性として，本調査では 大学生を対象としており, その大半 $(78 \%)$ が一人暮ら しをしていたためである可能性が考えられる.すなおち, 本調査協力者においては, アパート住まい等で近隣住民 との接触が少なく，「地域」という共同体が身近に存在 しておらず，このことが本結果に影響している可能性が 考えられる. この点については, 今後, 一般の地域住民 を対象とした調查データを用いて，地域に対する疎外意 識と主観的幸福感との関連を再検討することが重要であ る.

この椂に, 本研究の結果より, 一部有意な結果が得ら れなかったものの, 概して共同体からの疎外意識は人々 において主観的幸福感を低減させる傾向にあるものと考 えられる.ただし, 繰り返しとなるが, 本研究のデータ は大学生を対象として得られたものであり, その点にお いて制約があることは否定できない，そのため，本研究 で得られた知見の経験的妥当性を確認するためには，上 り豊かなサンプルを用いた，さらなる追試を行うことが 重要である．特に，上述した通り，地域に対する疎外意 識については，大学生を対象とした場合と一般の地域住 民を対象とした場合とでは，異なる結果が得られる可能 性が考えられるところである，ただし，上述したような 特別の理由が考えられない場合には，共同体に対する疎 外意識と主観的幸福感の間に成立する一般的な関係につ いては，それが大学生においてのみ成立するという明確 な根拠はとりたてて見当たらず，それ故，本研究の知見 にも一定の妥当性があるものと考えられる.

以上の結果を踏まえれば，国土・地域計画において， 幸福な社会の実現を目指寸上では，種々の共同体の再建 や人々の共同体意識の醸成を促すことが重要であるもの と言える. 例えば, 都市機能の充実化や幹線交通網の整 備等の各種の国土交通施策を通じて, 家族や地域コミュ ニティの紐帯を維持・強化することや国家に対するナシ ヨナリズムの形成を促すことが有効であると考えられる. そうした施策展開を通じて，人々の共同体精神の増進を 促すことが，人々の幸福感の醸成に寄与し得ることを， 
本研究の結果が示唆しているものと考えられる.今後は, こうした施策展開を実践するとともに，本研究で用いた 疎外尺度や主観的幸福感尺度を活用しながら，施策の効 果を検証することを通じて，実践的な研究取り組みを進 めていくことが重要である.

\section{参考文献}

1) VandenBos, G. R. (Ed.): APA Dictionary of Psychology, Washington, DC: American Psychological Association, 2007.

2) Kahneman, D., Diener, E., and Schwarz, N. (Eds.): WellBeing: The Foundations of Hedonic Psychology, New York: Russell-Sage, 1999.

3) Diener, E.: Subjective well-being, Psychological Bulletin, Vol.95, No.3, pp.542-575, 1984.

4) Diener, E.: Subjective well-being: Three decades of progress, Psychological Bulletin, Vol.125, No.2, pp.276302, 1999.

5) Baumeister, R. F. and Leary, M. R.: The need to belong: Desire for interpersonal attachments as a fundamental human motivation, Psychological Bulletin, Vol.117, No.3, pp.497-529, 1995.

6) Myers, D. G.: Close relationships and quality of life, In Kahneman, D., Diener, E. and Schwarz, N.(Eds.): Wellbeing: The Foundations of Hedonic Psychology, New York: Russell-Sage, pp.374-391, 1999.

7) G. W. F. ヘーゲル (長谷川宏訳) : 精神現象学, 作品社, 1998.

8) Argyle, M.: Causes and correlates of happiness, In Kahneman, D., Diener, E. and Schwarz, N.(Eds.): Wellbeing: The Foundations of Hedonic Psychology, New York: Russell-Sage, pp.353-373, 1999.

9) Diener, E. and Ryan, K.: Subjective well-being: A general overview, South African Journal of Psychology, Vol. 39, No.4, pp.391-406, 2008.

10) Diener, M. L. and McGavran, M. B.: What makes people happy? A developmental approach to the literature on fam- ily relationships and well-being, In R. Larsen and M. Eid (Eds.): The Science of Subjective Well-Being, New York, NY: Guildford Press, 2008.

11) Barden, R. C., Garber, J., Leiman, B., Ford, M. E., and Masters, J. C.: Factors governing the effective remediation of negative affect and its cognitive and behavioral consequences, Journal of Personality and Social Psychology, Vol.49, pp.1040-1053, 1985.

12) Harris, P. B., Werner, C. M., Brown, B. B., and Ingebritsen, D.: Relocation and privacy regulation: A cross-cultural analysis, Journal of Environmental Psychology, Vol.15, pp.311-320, 1995.

13) Altman, I. and Low, S.: Place Attachment, New York: Plenum, 1992.

14) Andrews, F. M., and Withey, S. B.: Social Indicator of Well-being: America's Perception of Life Quality, New York: Plenum, 1976.

15) Diener, E., Emmons, R. A., Larsen, R. J., and Griffin, S.: The satisfaction with life scale, Journal of Personality Assessment, Vol.49, No.1, 1985.

16) Västfjäll, D. and Gärling, T.: Development and aging: Validation of a Swedish short self-report measure of core affect, Scandinavian Journal of Psychology, Vol.48, pp.233-238, 2007.

17) Pavot, W. and Diener, E.: Review of the satisfaction with life scale, Psychological Assessment, Vol.5, pp.164-172, 1993.

18）大石繁宏 : 幸せを科学する, 新曜社, 2009 .

19) 羽鳥剛史, 中野剛志, 藤井聡 : ナショナリズムと市 民社会の調和的関係についての実証的研究，人間環 境学研究, Vol.8, No.2, pp.163-168, 2010.

20) 渡邊望, 羽鳥剛史, 藤井聡, 竹村和久：近代大衆社 会における人間疎外と大衆性についての実証的研究, 土木計画学研究・講演集, Vol.40, 2009.

21) Lyubomirsky, S., Sheldon, K. M., and Schkade, D.; Persuing happiness: The architecture of sustainable change, Review of General Psychology, Vol. 9, pp.111-131, 2005.

(2011.2. 25 受付)

\section{THE INFLUENCES OF A SENSE OF ALIENATION FROM COMMUNITIES ON SUBJECTIVE WELL-BEING}

\section{Natsuki KITAGAWA, Haruna SUZUKI, Tsuyoshi HATORI and Satoshi FUJII}

The purpose of this study was to examine the influences of a sense of alienation from four types of communities (i.e., family, organization, region, and nation) on subjective well-being (SWB). Using the existing scales of SWB which were composed of "Affective SWB" and "Cognitive SWB" and "alienation scales" developed on the basis of Hegel's theory, the associations between SWB and a sense of alienation from communities were examined. According to the obtain data, it was indicated that a sense of alienation from communities may have negative influences on SWB. 